\title{
METODE PEMBELAJARAN ENTREPRENEURSHIP UNTUK GURU SMK DI KABUPATEN LAMONGAN
}

\author{
Endang Sudarsih, SE, M.Si,MT* \\ Muchammad Nurif, SE. MT
}

\begin{abstract}
This study is about a training of learning method for teachers, especially who teaches the subject of entrepreneurship in Senior High School. The target of the study is Vocational High School teachers in Lamongan. Some crucial problems that are faced by the most of educational institution are teachers' low ability in finding references for students' problem solutions. Their leakage of creativity and innovation will cause a lower level of students' readiness to enter job fields after graduation. The goal of the study is to increase human resource quality in mastering learning methods that possible to be applied in entrepreneurship teaching-learning activities.

By using an appropriate method, it is expected that it will improve teachers' ability in finding references, developing creativity and innovations. Therefore, teachers enjoy teaching entrepreneurship subject with better spirits and students' entrepreneurship spirit will also developed earlier.
\end{abstract}

Kata Kunci: lecture of entrepreneurship, kreatif dan inovatif, teacher, student

Globalisasi ekonomi dan era informasi mendorong industri menggunakan sumber daya manusia lulusan lembaga pendidikan yang kompeten dan memiliki jiwa entrepreneurship. Akan tetapi tidak setiap lulusan pendidikan (utamanya lulusan SMU dan SMK) ternyata memiliki jiwa entrepreneurship seperti yang diinginkan oleh dunia kerja. Kenyataan menunjukkan bahwa hanya sebagian kecil lulusan pendidikan kita memiliki jiwa entrepreneurship. Di sisi lain, krisis ekonomi menyebabkan jumlah lapangan kerja tidak tumbuh, dan bahkan berkurang karena bangkrut. Dalam kondisi seperti ini, maka lulusan pendidikan (SMK) dituntut untuk tidak hanya mampu berperan sebagai pencari kerja (job seeker) tetapi juga harus mampu berperan sebagai pencipta lapangan kerja (job creater). Pada kenyataannya, baik mereka yang ingin mencari kerja maupun yang ingin menciptakan lapangan kerja dituntut untuk memiliki iwa entrepreneurship. Oleh karena itu penting sekali menekan dunia pendidikan agar melakukan berbagai inovasi untuk memenuhi

\footnotetext{
${ }^{*}$ Dosen UPM Soshum ITS
}

jsh Jurnal Sosial Humaniora, Vol 4 No.1, Juni 2011 
tuntutan tersebut. Diantaranya adalah inovasi pembelajaran dalam membangun generasi entrepreneurship di era informasi sekarang ini.

Ada suatu pendapat yang mengatakan bahwa, saat ini sebagian lulusan pendidikan kita masih lemah jiwa entrepreneurship-nya. Sedangkan sebagian kecil yang telah memiliki jiwa entrepreneurship umumnya berasal dari keluarga pengusaha atau pedagang. Namun faktanya menunjukkan bahwa entrepreneurship adalah merupakan jiwa yang bisa dipelajari dan diajarkan. Bahkan berbagai literature mendukung konsep ini. Seorang yang memiliki jiwa entrepreneurship umumnya memiliki potensi menjadi pengusaha, tetapi bukan jaminan menjadi pengusaha. Sedangkan pengusaha pada umumnya memiliki jiwa entrepreneurship.

Proses pembelajaran yang lebih menekankan pada konsep dan teori merupakan salah satu tahap yang perlu dilewati untuk menanamkan kemampuan ilmiah dan logika siswa berwirausaha. Tahap ini perlu dirancang sedemikian rupa agar dapat menumbuhkan jiwa kreatif dan inovatif siswa, karena kedua hal ini penting dalam berbisnis. Pada tahap berikutnya proses pembelajaran dapat ditingkatkan dengan model pendidikan inkubator bisnis berbasis teknologi. Model ini dirancang sebagai usaha untuk mensinergikan teori (20\%) dan praktek (80\%) dari berbagai kompetensi bidang ilmu yang diperoleh dalam bidang teknologi dan industri. Inkubator bisnis ini dapat dijadikan pusat kegiatan pembelajaran kewirausahaan dengan atmosfir bisnis yang kondusif serta didukung oleh fasilitas laboratorium yang memadai.

Sekolah Menengah Kejuruan merupakan sekolah yang proses pembelajarannya dirancang untuk menyiapkan siswanya siap memasuki dunia kerja pasca lulus sekolah. Merancang metode pembelajaran yang memadukan kemampuan dan softskill siswa sangat diperlukan. Terutama metode pembelajaran dalam mata pelajaran entrepreneurship.

Jumlah Sekolah Menengah Kejuruan (SMK) di Kabupaten Lamongan sebanyak 54 sekolah, yang tersebar di seluruh wilayah kecamatan, yang terdiri dari 6 SMK Negeri dan 48 SMK Swasta. Dari 54 SMK tersebut, yang diambil sebagai peserta pelatihan sebanyak 40 SMK yaitu 6 SMK Negeri dan 34 SMK Swasta. 
Menatap masa depan berarti mempersiapkan generasi muda yang memiliki kecintaan terhadap pembelajaran dan merupakan terapi kesehatan jiwa bagi anak bangsa. Munculnya generasi entrepreneurship dari proses pembelajaran mata pelajaran Entrepreneurship ini diharapkan dapat memberikan solusi atas permasalahan yang dihadapi dunia pendidikan kita yang pada akhirnya dapat mengurangi jumlah pengangguran intelektual yang ada saat ini. Selain itu juga bisa menjadi arena untuk meningkatkan kualitas SDM dalam penguasaan IPTEK, sehingga bisa dipersiapkan tenaga handal sejak dini untuk menghadapi kompetisi global. Mulailah dari diri sendiri untuk berbuat sesuatu guna menciptakan pendidikan yang bisa lebih baik dan berkualitas, karena ini akan menyangkut masa depan anak-anak bangsa kita.

Disinilah letak benang merahnya, bahwa dengan pembelajaran Entrepreneurship ini, kita sebenarnya sedang mengubah wajah pendidikan menengah ini secara dramatis. Bayangkan anak didik kita akan memiliki kemampuan kreatif dan inovatif dalam melihat dan menciptakan kesempatan serta mewujudkannya menjadi sesuatu yang lebih berharga secara ekonomis, sosial maupun ekologi. Dan itu semua terjadi karena setiap siswa telah terbangkitkan jiwa entrepreneurship-nya sejak awal. Untuk itu kesiapan para guru pengampu mata pelajaran Entrepreneurship akan meningkat dengan adanya kegiatan pelatihan metode pembelajaran ini.

Berdasarkan uraian di atas beberapa permasalahan yang dihadapi oleh para guru pengampu mata pelajaran Entrepreneurship di Kabupaten Lamongan adalah:

a. Adanya kurangnya kemampuan / referensi yang dimiliki para pengampu/guru mata pelajaran Entrepreneurship di Sekolah Kejuruan.

b. Adanya kurangnya kemampuan daya kreatif dan inovatif yang dimiliki oleh para pengampu/guru mata pelajaran Entrepreneurship di Sekolah Kejuruan.

c. Adanya Ketidaksiapan siswa Sekolah Kejuruan dalam memasuki dunia kerja pasca lulus.

\section{Tujuan}

a. Meningkatkan kemampuan / referensi yang dimiliki para pengampu/guru mata pelajaran Entrepreneurship di Sekolah Kejuruan. 
b. Meningkatkan kemampuan kreatif dan inovatif yang dimiliki oleh para pengampu/guru mata pelajaran Entrepreneurship di Sekolah Kejuruan.

c. Mempersiapkan siswa Sekolah Kejuruan dalam memasuki dunia kerja pasca lulus.

\section{Manfaat}

Memberikan konsep dan wawasan serta pembekalan pada para pengampu / guru dalam metode pembelajaran mata pelajaran Entrepreneurship di Sekolah Menengah Kejuruan (SMK) di Kabupaten Lamongan.

\section{Tinjauan Pustaka}

Enterpreneurship

Peter Druker mengungkapkan bahwa entrepreneurship selalu mencari perubahan, menanggapinya dan memanfaatkan sebagai peluang. Mereka adalah orang yang mampu melakukan kombinasi-kombinasi baru pekerjaan yang lebih cerdik dan kerja lebih luas dan berorientasi laba, termasuk adany keberanian menghadapi resiko yang telah di pertimbangkan sebelumnya. Bahkan Mc. Clelland mengatakan entrepreneurship memiliki karakter tertentu yang merujuk pada kebutuhan akan berprestasi atau yang disebut Need of Achivement (N-Ach) antara lain :

a. Lebih menyukai pekerjaan dengan resiko yang realistik

b. Bekerja lebih giat pada tugas-tugas yang memerlukan kemampuan mental

c. Tidak menjadi bekerja lebih giat dengan adanya imbalan uang

d. Ingin bekerja pada situasi yang dapat diperoleh pencapaian pribadi (personal achievement)

e. Menunjukkan kinerja yang lebih baik dalam kondisi yang memberikan umpanbalik yang jelas dan positif

f. Cenderung untuk berpikir ke masa depan dan memiliki pemikiran untuk jangka panjang

g. Ukuran N-Ach dapat menunjukkan bagaimana jiwa wirausaha seseorang, makin besar/ tinggi nilai $\mathrm{N}$-Ach seseorang, maka akan makin besar pula bakat potensialnya untuk menjadi wirausahawan yang sukses. 
Enterpreneurship merujuk kepada kepribadian tertentu, yaitu pribadi yang mulia, yang mampu berdiri di atas kemampuan/kekuatan sendiri, yang mampu mengambil keputusan untuk dirinya sendiri serta mampu menerapkan tujuan yang ingin dicapai atas pertimbangannya sendiri. Setiap usaha yang dijalankan, bahkan oleh mereka yang sukses, senantiasa dimulai dengan adanya semangat kewirausahaan (enterpreneurship spirit). Julian B. Rotter, menyebut Enterpreneurship sebagai Locus of Control Internal, yaitu mereka yang suskses dalam bisnis adalah mereka yang merasa bahwa keberhasilan lebih ditentukan oleh usaha-usaha pribadi, adanya perjuangan/motivasi internal untuk mencapai kemandirian. Locus of control internal yang tinggi ditandai dengan adanya keyakinan bahwa mereka memiliki kontrol/kendali atas lingkungannya.

Buchori Alma, mengatakan bahwa jika diperhatikan manfaat menjadi seorang enterpreneur sangatlah banyak. Manfaat itu antara lain sebagai berikut:

a. menambah daya tampung tenaga kerja, sehingga dapat mengurangi jumlah pengangguran.

b. Sebagai generator pembangunan lingkungan, bidang produksi, distribusi, pemeliharaan lingkungan dan kesejahteraan masyarakat.

c. Menjadi contoh anggota masyarakat lain, sebagai pribadi unggul yang patut dicontoh, diteladai, karena seorang enterpreneur itu adalah orang yang jujur, terpuji, berani, hidup tidak merugikan orang lain.

d. Selalu menghormati hukum dan peraturan yang berlku, berusaha selalu memperrjuangkan lingkngan.

e. Berusaha memberi bantuan kepada orang lain dn pembangunan sosial sesuai dengan kemampuannya.

f. Berusaha mendidik karyawannya menjadi orang mandiri, disiplin, jujur, tekum dalam menghadapi pekerjaan.

g. Memberi contoh bagaimana kita harus bekerja keras, tetapi tidak melupakan perintah-perintah agama, dekat kepada Allah SWT.

h. Hidup ssecara efisien, tidak berfoya-foya dan tidak boros. 
i. Memelihara keserasian lingkungan, baik dalam pergaulan maupun kebersihan lingkungan.

\section{Model Pembelajaran}

Pembelajaran yang monoton dan membosankan masih sering terjadi di ruang-ruang kelas. Akibatnya siswa kurang bergairah dlam menyerap materi yang disampaikan guru. Hal ini dapat disebabkan kekurangpahaman para guru terhadap berbagai model pembelajaran yang ada. Sehingga langkah-langkah pembelajaran (yang tercantum dalam rencana pembelajaran) masih mengacu pada contoh-contoh standar rencana pembelajaran yang ada. Padahal seyogyanya langkah-langkah pembelajaran dibuat sevariatif mungkin dengan tetap memperhatikan relevansinya terhadap ketercapaian tujuan pembelajaran.

Beberapa langkah pembelajaran yang dapat dipertimbangkan para guru guna memperkaya langkah-langkah pembelajaran yang akan dilakukan

1. Examples non examples, dengan langkah-langkahnya sebagai berikut:

a. Guru mempersiapkan gambar-gambar sesuai dengan tujuan pempelajaran.

b. Guru menempelkan gambar di papan atau ditayangkan melalui OHP/LCD

c. Guru memberi petunjuk dan memberi kesempatan pada siswa untuk memperhatikan/menganalisa gambar.

d. Melalui diskusi kelompok 2-3 orang siswa, hasil diskusi dari analisa gambar tersebut dicatat pada kertas.

e. Tiap kelompok diberi kesempatan membaca hasil diskusinya.

f. Mulai dari koemntar/hasil diskusi siswa, guru mulai menjelaskan materi sesuai tujuan yang ingin dicapai.

g. Kesimpulan

2. Picture and picture, dengan langkah-langkahnya sebagai berikut

a. Guru menyampaikan kompetensi yang ingin dicapai.

b. Menyajikan materi pengantar.

c. Guru menunjukkan/memperlihatkan gambar-gambar kegiatan keterkaitan dengan materi. 
d. Guru menunjuk/memanggil siswa secara bergantian

e. Guru menanyakan alasan/dasar pemikiran urutan gambar tersebut.

f. Dari alasan/urutan gambar tersebut guru memulai menanamkan konsep/materi sesuai dengan kompetensi yang ingin dicapai.

g. Kesimpulan/rangkuman.

3. Numbered heads together (Kepala Bernomor, Spencer Kagan,1992), dengan langkah-langkahnya sebagai berikut

a. Siswa dibagi dalam kelompok, setiap siswa dalam setiap kelompok mendapat nomor.

b. Guru memberikan tugas dan masing-masing kelompok mengerjakannya.

c. Kelompok mendiskusikan jawaban yang benar dan memastikan tiap anggota kelompok dapat mengerjakannya/mengetahui jawabannya.

d. Guru memanggil salah satu nomor siswa dengan nomor yang dipanggil melaporkan hasil kerjasama mereka.

e. Tanggapan dari teman yang lain, kemudian guru menunjuk nomor yang lain.

f. Kesimpulan.

4. Think Pair and Share (Frank Lyman, 1985), dengan langkah-langkahnya sebagai berikut

a. Guru menyampaikan inti materi dan kompetensi yang ingin dicapai.

b. Siswa diminta untuk berfikir tentang materi/permasalahan yang disampaikan guru.

c. Siswa diminta berpasangan dengan teman sebelahnya (kelompok 2 orang) dan mengutarakan hasil pemikiran masing-masing.

d. Guru memimpin pleno kecil diskusi, tiap kelompok mengemukakan hasil diskusinya.

e. Berawal dari kegiatan tersebut

5. Mind Mapping, dengan langkah-langkahnya sebagai berikut

a. Guru menyampaikan kompetensi yang ingin dicapai

b. Guru mengemukakankonsep/permasalahan yang akan ditanggapi oleh siswa/sebaiknya permasalahan yang mempunyai alternatif jawaban.

c. Membentuk kelompok yang anggotanya 2-3 orang. 
d. Tiapkelompon menginventarisasi/menctat alternatif jawaban hasil diskusi.

e. Tiap kelompok (atau diacak kelompok tertentu) membaca hasil diskusinya dan guru mencatat di papan dan mengelompokkan sesuai kebutuhan guru.

f. Dari data-data di papan siswa diminta membuat kesimpulan atau guru memberi bandingan sesuai konsep yang disediakan guru

\section{Metode Yang Digunakan}

Beberaoa metode yang digunakan dalam pelatihan ini adalah sebagai berikut:

a. Small Group Discussion, yaitu Bagaimana menilai dan mengembangkan potensi enterpreneurship seseorang

b. Penugasan Self Directed Learning, yaitu menilai potensi diri sendiri, rencana pengembangannya dan menganalisis "successs story" berdasar knowledge yang sudah dipahami

c. Discovery Learning, yaitu Metode pengajaran yang dilakukan dengan memberikan data masalah-masalah akurat yang harus dicarikan solusi pemecahannya.

d. Simulasi, yaitu dengan menggugah Otak Bawah Sadar akan pentingnya mindset keuangan, spirit berprestasi, pembelajaran, dan kemandirian

\section{Hasil Dan Pembahasan}

Langkah awal yang dilakukan dalam pelatihan ini adalah melakukan survey lokasi keberadaan SMK yang dituju, yaitu ke Dinas Pendidikan Lamongan. Berdasarkan hasil survey awal ini diketahui bahwa jumlah SMK yang ada di Kabupaten Lamongan adalah sebanyak 56 SMK. Dengan pertimbangan kemampuan dan kebutuhan SMK, maka dipilih 40 SMK dimana masing-masing sekolah mengirimkan 1 (satu) orang wakil untuk mengikuti kegiatan pelatihan ini. Target pelatihan metode pembelajaran mata pelajaran entrepreneurship adalah 40 orang guru SMK di Kabupaten Lamongan.

Berdasarkan pertimbangan waktu dan kebutuhan yang mendasar, maka disain atau metode pelatihan yang digunakan hanya dua yaitu

a. Small Group Discussion 
Bagaimana menilai dan mengembangkan potensi enterpreneurship seseorang. Peserta dibagi dalam beberapa kelompok kecil selanjutnya dipandu oleh seorang instruktur untuk diskusi memecahkan permasalahan yang dihadapi oleh sekolah masing-masing.

\section{b. Simulasi}

Untuk menggugah Otak Bawah Sadar akan pentingnya mindset keuangan, spirit berprestasi, pembelajaran, kemandirian, perencanaan, kreativitas, dan berani mengambil resiko. Tahapan proses yang telah dilaksanakan, pertama kita membuat dan mengirimkan undangan ke sekolah yang dipilih untuk mengirimkan seorang yang diutus untuk mengikuti pelatihan.

Peserta sangat antusias mengikuti kegiatan pelatihan ini hingga selesai. Pertanyaan dari peserta sering kali muncul di tengah para pemateri memberikan materi pelatihan. Selama proses pelatihan berjalan, terungkap bahwa jarang sekali ada pelatihan metode pembelajaran mata pelajaran entrepreneurship khususnya, bagi guru-guru SMK swasta. Biasanya yang ada adalah pelatihan untuk guru-guru SMA. Bahkan yang sering diundang untuk mengikuti pelatihan adalah guru-guru SMA atau SMK negeri. Dari 40 orang peserta yang mengikuti pelatihan, hingga pelatihan usai berkurang 3 orang dikarenakan ada keperluan lain.

Untuk mengukur tingkat kesuksesan pelatihan ini, maka digunakan feed back yang meliputi materi yang disampaikan; ruang pelatihan; pemateri; dan konsumsi. Jawaban yang disediakan adalah pilihan 4 alternatif jawaban terhadap pelaksanaan kegiatan pelatihan ini (sangat memuaskan; memuaskan; kurang memuaskan; tidak memuaskan). Hasil feed back yang mengukur tingkat kepuasan peserta pelatihan sebagaimana yang disajikan dalam tabel1 dibawah ini.

Tabel 1

Tingkat Kepuasan Peserta Pelatihan

\begin{tabular}{|l|c|c|c|c|}
\hline & $\begin{array}{c}\text { Tidak } \\
\text { Memuaskan }\end{array}$ & $\begin{array}{c}\text { Kurang } \\
\text { Memuaskan }\end{array}$ & Memuaskan & $\begin{array}{c}\text { Sangat } \\
\text { Memuaskan }\end{array}$ \\
\hline Materi & - & - & 12 & 25 \\
\hline Ruang & - & - & 37 & - \\
\hline Pemateri & - & - & 22 & 15 \\
\hline Konsumsi & - & - & 37 & - \\
\hline
\end{tabular}


Dari 37 peserta pelatihan, 25 orang menyatakan bahwa materi dalam pelatihan ini sangat memuaskan dan perlu ada pelatihan seperti ini lagi karena sangat bermanfaat. 12 orang peserta menyatakan bahwa materi dalam pelatihan ini memuaskan dan bila perlu waktu diperpanjang lagi tidak hanya 2 (dua) hari. Kalau perlu diselingi dengan film-film yang menarik, contoh kasus, game dan out bound Mereka berharap agar pihak Perguruan Tinggi juga sesekali turun ke bawah melihat secara langsung proses belajar mengajar di SMK Lamongan.

Sebagian besar peserta menyatakan bahwa tempat atau ruang memuaskan, meskipun ruangan tidak ber AC namun cukup memadai.

Pembicaranya menarik dan sangat memuaskan dalam menyampaikan materi, meskipun waktu untuk diskusi sangat singkat. Ada peserta yang menyatakan pelatihan seperti ini bisa diadakan 2 kali setahun. Peserta yang diundang lebih banyak lagi (seluruh guru Entrepreneurship di SMK se Kabupaten Lamongan). Alasannya, walaupun mereka selaku guru entrepreneurship bukan berarti faham betul tentang masalah konsep entrepreneurship. Untuk itu mereka membutuhkan supaya pihak luar sekolah yang lebih berpengalaman melalukan sharing pengalamannya kepada SMK lain, terutama SMK swasta yang terpencil lokasinya.

\section{Kesimpulan Dan Saran}

Berdasarkan wawancara dengan para peserta pelatihan pada kegiatan ini, bahwa di tingkat Sekolah Menengah Kejuruan pelatihan-pelatihan metode pembelajaran yang aplikatif sangat diperlukan untuk meningkatkan kemampuan guru. Demikian juga pembelajaran terhadap akses teknologi komunikasi dan informasi perlu ditingkatkan untuk membantu para guru SMK di daerah ini mengembangkan referensinya dan menciptakan daya kreatif dan inofatif yang harus dimiliki oleh seorang guru, terutama guru SMK. Dengan demikian maka tujuan untuk menyiapkan siswa yang siap memasuki pasca lulus sekolah dapat tercapai.

Selain itu ada ketimpangan atas keterlibatan guru-guru SMK yang berpeluang mengikuti pelatihan-pelatihan semacam itu, khususnya antara SMK Negeri dengan SMK swasta. 
Beberapa masukan yang disarankan untuk melengkapi studi tentang pelatihan metode pembelajaran mata pelajaran entrepreneurship ini adalah sebagai berikut:

1. Perlu dilakukan pelatihan metode pembelajaran mata pelajaran entrepreneurship beberapa kali dalam setahun, sehingga semua guru SMK di Kabupaten Lamongan dapat dipastikan mengikuti kegiatan tersebut.

2. Perlu dibangun network (jaringan) antara guru mata pelajaran entrepreneurship di SMK Negeri dan Swasta untuk menyamakan persepsi tentang konsep dan prioritas pada mata pelajaran entrepreneurship. Selain itu sebagai wadah untuk sharing pengalaman demi meningkatkan wawasan para guru.

3. Perlu ada penelitian yang mengkaji praktek-praktek pembelajaran mata pelajaran entreprenurship pada SMK-SMK, khususnya yang di daerah supaya mendapat gambaran yang terpadu tentang kompleksitas pembentukan jiwa entrepreneurship sejak dini.

\section{Daftar Pustaka}

Brandt, Steven, Entreprenuership, Effhar Dahara Prize, Jakarta, 1995

Buchori Alma, Kewirausahaan, Panduan Perkuliaan, Penerbit Alfabeta, Bandung, 1999.

http/www,scrid.com/doc/8969878/model- Pembelajaran Efektif

Masykur Wiratmo, Pengantar Kewirausahaan; Kerangka Dasar Memasuki Dunia Bisnis,

BPFE-Yogyakarta, Yogyakarta, 1996

Tim Entrepreneurship ITS, Entrepreneurship, ITSPress, Surabaya, 2009 